\title{
EARTHQUAKE MITIGATION BASED ON LOCAL WISDOM : THE VERNACULAR ARCHITECTURE CONCEPT OF DASAN BELEQ TRADITIONAL HOUSE IN NORTH LOMBOK - INDONESIA
}

\author{
Yuli Susanthi ${ }^{1, *}$, Riyo Rosi Meisandy ${ }^{2}$, Alinda Nisa ${ }^{3}$ \\ ${ }^{1}$ Geography Education, Universitas Negeri Yogyakarta \\ ${ }^{2}$ Geography Education, Universitas Negeri Malang \\ ${ }^{3}$ Disaster Management, Universitas Gadjah Mada \\ *Email: yulisusanthi.2020@ student.uny.ac.id
}

\begin{abstract}
Lombok Regency is one of the zones with a high earthquake hazard potential in Indonesia. However, as an area located in that city, Dasan Beleq Hamlet, Gumantar village did not get any physical damage by the disaster in 2018. The customary system and local wisdom in building houses applied by the society supported their houses to have earthquake resistance. This study aimed to investigate the local wisdom portrayed in the Dasan Beleq traditional houses for earthquake mitigation purposes. This research was a descriptive qualitative study conducted from September to December 2020. The result showed that the local wisdom of the traditional houses was represented by their materials and construction techniques. Techniques for connecting ropes and pegs between poles, roof, poles, and floors were arranged using natural resources and settled semi-permanently based on some believed rules of building earthquake-resistant houses. The people also maintained the local wisdom and customary values by applying some special guidelines and rituals in the process of building their houses.
\end{abstract}

Keywords: Earthquake; Local Wisdom; Mitigation; Traditional House.

\section{A. INTRODUCTION}

As one of the regions in Central Indonesia, Lombok had a high level of earthquake risk potential (Pradono, 2018), supported by the data from the National Earthquake Study Center Team, which recorded the disaster that occurred on July 29 to August 31, 2018. At that time, the earthquake with a magnitude of 6.9 SR happened three times, with 484 times aftershocks. The successive earthquakes were most likely caused by the same fault system activities, namely local faults outstretched along the north coast of Lombok Island (Karima et al., 2020).

Material and spiritual losses were obtained by society as the result of the tragedy. The National Disaster Management Agency documented physical damage data consisting of 83,392 housing units and 3,540 public and social facilities that could no longer be used (Nugroho, 2018). Furthermore, the disaster also caused hundreds of 
deaths, thousands of injured victims, and refugees (Wismabrata, 2018).

The earthquake was a disaster caused by volcanic and tectonic activities affecting the earth's surface movement. The release of energy from the earth's core both volcanically and tectonically affected sudden and unavoidable actions (Husein, 2015; Nur, 2010). This condition required people to always be ready for disaster mitigation efforts for the sake of reducing the losses; one of the means was by building earthquakeresistance construction through considering the local wisdom.

Local wisdom could be understood as a view of life and knowledge as well as several life strategies portrayed in some activities carried out by local communities to answer many problems in fulfilling their daily needs (Dahliani et al., 2015; Marlina et al., 2020). (Hairumini et al., 2017) stated that local wisdom was an effort to reduce the impact of disasters since it came from the human ability to understand the environment to survive. The values of particular local wisdom became an attempt to establish a good relationship between nature and humans.

The local wisdom maintained by the society was considered to be one of the most effective disaster mitigation efforts. Local wisdom could be manifested as adaptive behavior to the environment for reducing disaster risk since it was gained from ancient people's numerous experiences (Suparmini et al., 2014). Several studies had also proved that since the 1970s, local wisdom could increase society's preparedness for facing natural disasters (Zulfadrim et al., 2018). That was also reinforced by the fact that some earthquake-prone areas in Indonesia which utilized their local wisdom could reduce the disaster risk.

Located in the Kayangan District, North Lombok regency, Gumantar village was inhabited by indigenous Sasak Tribe people. The community used the Dasan Beleq traditional house as a place to live. Based on data from the National Disaster Management Agency, Gumantar Village did not get any material damage after having an earthquake in 2018. The customary system and local wisdom implemented by the community in building houses braced their buildings to have earthquake resistance. This study intended to analyze the practice of earthquake mitigation based on local wisdom in the Dasan Beleq traditional houses. 


\section{B. MATERIALS AND METHODS}

This research was a descriptive qualitative study. A qualitative study was a naturalistic inquiry carried out in natural conditions (Sugiyono, 2016). This study was a phenomenological approach that focuses on the conscious experience of indigenous peoples in building their houses.

Phenomenology was an approach started by Edmund Husserl and developed by Martin Heidegger to understand and study the experience of human life (Mac \& Robinson, 2001). Phenomena that are the focus of phenomenology were assumed as a character of lived experience. Heidegger, dwelt on "phenomena" as what appears or shows up to us in our everyday activities (Bermudez et al., n.d.).The general focus of this approach was to examine the essence or structure of experience into human consciousness (Tuffour, 2017). Therefore, phenomenological approach is the most appropriate approach to find out local wisdom in the Dasan Beleq traditional house in earthquake mitigation efforts.

This research was conducted in Dasan Beleq Hamlet, Gumantar Village, Kayangan District, North Lombok Regency from September to December
2020. The map of the research location can be seen in the Figure 2. Data collection was carried out through interviews, observation and documentation. In-depth interviews were conducted with 6 selected informants which included 3 indigenous people, 1 traditional leader, hamlet head, and village head. Data was also collected through observation, and documentation containing information related to the Dasan Beleq traditional house and the lives of its people. Furthermore, the validity of the data was tested using triangulation techniques. This technique aims to compare data from various sources.

Data analysis was carried out through three stages, namely data reduction, data presentation, and drawing conclusions as shown in the Figure 1. Data reduction is done by collecting and simplifying data from interviews, observations, and documentation based on concepts and categories. Data presentation is done by compiling information about the traditional house of Dasan Beleq and the life of the people in the form of narrative text. The conclusions are drawn or verification of the data presented. 


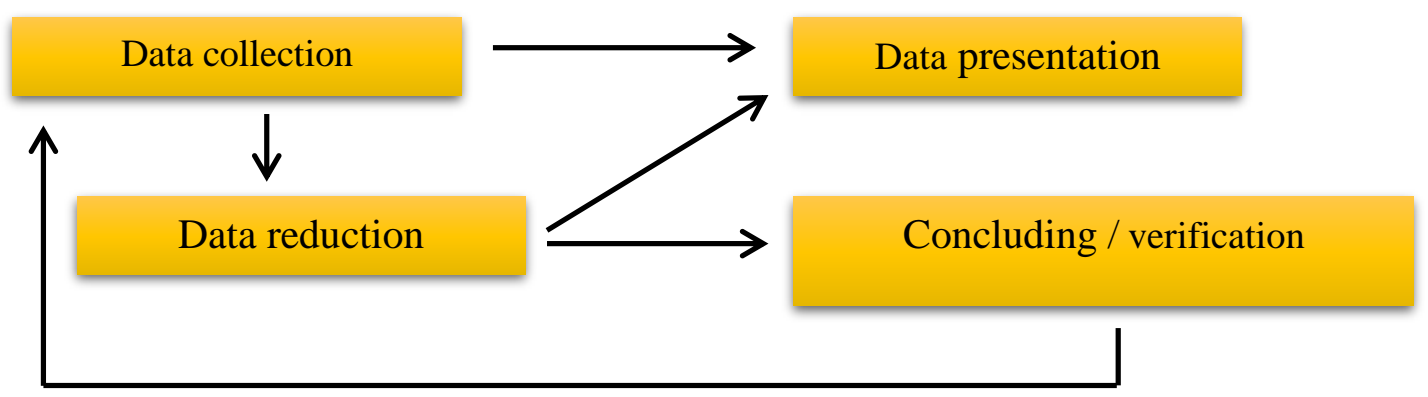

Source: Sugiyono, 2016

Figure 1. Data Analysis Stages

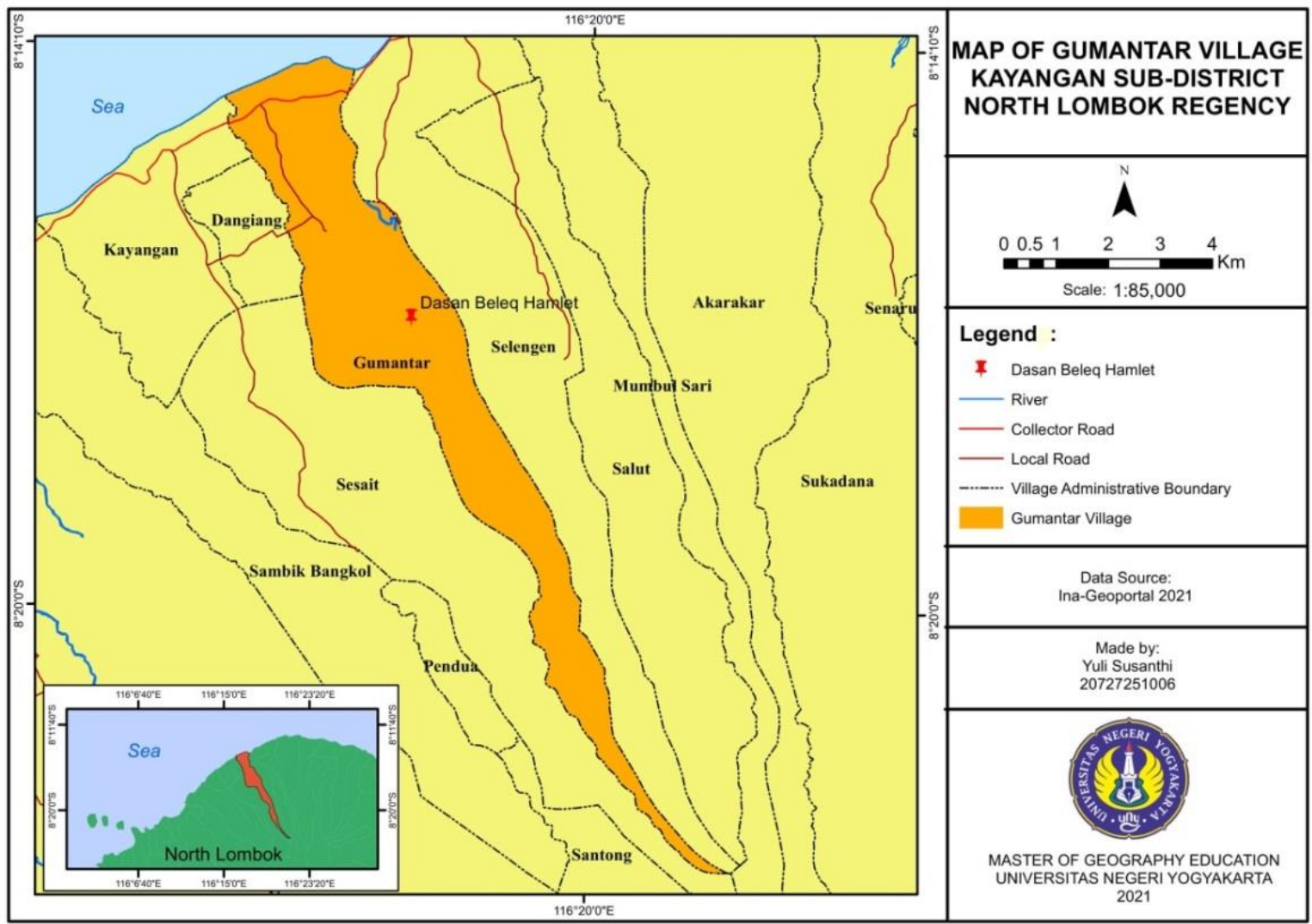

Figure 2. Research Location

\section{RESULTS AND DISCUSSION}

\section{General Description of the Dasan}

\section{Beleq Community}

Dusun Located in Gumantar

Village, Kayangan District, East Lombok

Regency, Dasan Beleq Hamlet was inhabited by indigenous Sasak tribe people. Based on the data attained from an interview with the hamlet head, the number of families staying in that area was around 100 in 2020. They lived in the Dasan Beleq traditional houses consisting 
of 30 buildings. They strongly maintained their customary values. Most of them were Muslims and worked as farmers.

For society, customary stakeholders played an important role in implementing the determined policies. The order of the customary stakeholders was based on their lineage, consisting of Kyai, Mangku, Pemekel, Raden, and Turun. Kyai (penghulu) was responsible for traditional religious rituals. Furthermore, Mangku (government holder) had control for rituals related to the earth/nature and its contents. Pemekel (prosecutor) had responsibility for regulating the application of customary law. Moreover, Raden was in control of performing circumcision in traditional rituals. Additionally, Turun (customary police) was in charge of investigating problems related to the implementation of the customary law.

\section{The Dasan Beleq Traditional House as}

a Form of Earthquake Mitigation

\section{Based on Local Wisdom}

The Dasan Beleq traditional building was a residential house for the indigenous Sasak tribe people. The construction was built within the fence in a 2-hectare area. In general, the house was not too high aimed to enable anyone entering the building with a slightly bent body position to respect the owner. They believed that a house had involvement in natural and non-natural processes. The house material and shape were made as a manifestation of people's imagination by considering aesthetic, spirituality, and comfort and safety values for the residents (Alam et al., 2018).

For the Sasak tribe people, the house had a dual function, both for a shelter and a sacred place that should be preserved (Widisono, 2019). The people thought that inside their house remained the spirits of their ancestors who have died. Since the house functioned as a space for doing their daily activities, it had to be modified to meet their needs in demonstrating the prevailing attitudes, culture, and lifestyle (Dahliani et al., 2015). Therefore, the principle of building a Dasan Beleq traditional house was always attached to the customary rules applied in society.

The local wisdom strongly believed by the people of Dasan Beleq in making houses contained earthquake mitigation values. The building construction system was arranged based on the rules for earthquake-resistant houses as expressed by Triyadi et al., (2010) including 1) simple and symmetrical building plans, 2) regular and symmetrical arranged 
insulating walls, 3) the wall that attached to another wall or column, 4) the roof construction using a light material, and the roof truss firmly attached to the wall or column which functioned as a pedestal, 5) the foundation located on solid and flat ground, 6) the presence of connected columns or pillars (using binders), 7) connected beams and poles, 8) the reinforcement at the junctions of poles (columns) and beam rings, and 9) the presence of hooks/anchors between walls and posts.

Based on those principles, it could be seen that the people of Dasan Beleq Hamlet always paid attention to house construction techniques since their environmental condition was prone to earthquakes. Apart from the construction, the building materials also had an important role for earthquake mitigation purposes by the use of natural and environmentally friendly resources. In the architectural and cultural concept of traditional houses in Indonesia, engineering construction structures (connection and pedestal systems) with the exploration of local materials like stone, wood, and bamboo was seen as a human adaptation to nature (Ibrahim, 2011; Rapoport, 1969). Specifically, the role of building materials and shapes in the Dasan Beleq traditional house as earthquake mitigation can be seen in the table 1.

Table 1. Forms of Earthquake Mitigation Based on Local Wisdom at the Traditional House of Dusun Beleq

\begin{tabular}{lll}
\hline $\begin{array}{c}\text { Name of } \\
\text { building shape }\end{array}$ & $\begin{array}{c}\text { Building } \\
\text { material }\end{array}$ & \multicolumn{1}{c}{ Disaster mitigation } \\
\hline Pole & Wood & $\begin{array}{l}\text { The main foundation wood which is carved } \\
\text { and equipped with supporting stones and the } \\
\text { pile of palm fibers between the parts gives the } \\
\text { building strength when there is vibration on the } \\
\text { ground. }\end{array}$ \\
\hline $\begin{array}{lll}\text { Ropes between } \\
\text { poles and pegs }\end{array}$ & $\begin{array}{l}\text { Rope and } \\
\text { bamboo }\end{array}$ & $\begin{array}{l}\text { Between the parts of the house put together } \\
\text { using rope and bamboo as a peg (substitute for } \\
\text { nails) This technique makes the house flexible } \\
\text { between parts so that it is able to follow the } \\
\text { ground motion when an earthquake occurs. }\end{array}$ \\
& & $\begin{array}{l}\text { Each part of the building supports each other } \\
\text { and withstands shaking when an earthquake } \\
\text { occurs. }\end{array}$ \\
\hline Roof & $\begin{array}{l}\text { The alang-alang leaf material which is light in } \\
\text { nature and its distinctive preparation technique } \\
\text { make the roof of the house not easily collapse } \\
\text { when an earthquake occurs. }\end{array}$ \\
\hline & Alang-alang \\
& leaves &
\end{tabular}


Floor

Clay and stone

Floor material that comes from a mixture of soil and stone has a strength that makes the floor less likely to crack when there is vibration in the ground.

Based on the table above, it can be seen that the local wisdom of the Dasan Beleq traditional house for earthquake mitigation was revealed by the materials and manufacturing techniques. The use of wood and bamboo was in line with the recommendation for using environmentally friendly materials for the reason that they were renewable (Arief \& Subadyo, 2017). Each part of the house also had a vital role for earthquake shock resistance purposes. The utilization of wood and alang-alang for the roof made the buildings light. When the earthquake occurred, the buildings would only shake and did not collapse (Triyadi et al., 2010).

Moreover, six wooden supported poles had an imperative role in earthquake mitigation. Wood was known for withstanding compression/strains when a shock occurred (Maknun et al., 2016). At each bottom of the pillar, stones were put to separate the building from the ground as seen in figure $3 \mathrm{a}$. Besides strengthening the building, the stone also reduced vibrations during the earthquake (Maknun et al., 2016). A layer of fibers between stones and pillars as seen in Figure $3 b$ was used to increase the strength of traditional houses in resisting the earthquake shocks. This technique was believed by the people of Dasan Beleq as a hereditary legacy given by their ancestors.

Pegs and ropes between poles functioned as a substitute for nails strengthening each connection as shown in Figure 3c. Earthquake forces which usually caused a building to slide did not have a bad impact on buildings with good bonded foundation. This technique protected the foundation's power to withstand its position against any shifting of constructions during an earthquake (Hairumini et al., 2017). The cavity also allowed the connection to be flexible and moved according to earthquake waves (Syamsuri \& Sufianto, 2020). Furthermore, utilizing bamboo as a material for pegs and ropes between poles fortified the building construction. As a light material with fibrous morphology, hollow shape, and strong appeal, bamboo was the perfect material for buildings in earthquake-prone areas (Baghel \& Thakkar, 2017).

The strength of the Dasan Beleq traditional house was also supported by materials used on the floor. The mixture 
of soil and rock was proven to have a capacity for vibration resistance so that it did not crack during the earthquake. Based on the material, the floors could last for 2-3 years (Komalasari et al.,
2020). Besides vibration resistance, the people deliberately used natural materials on the floors to maintain the customary values believed by the community.
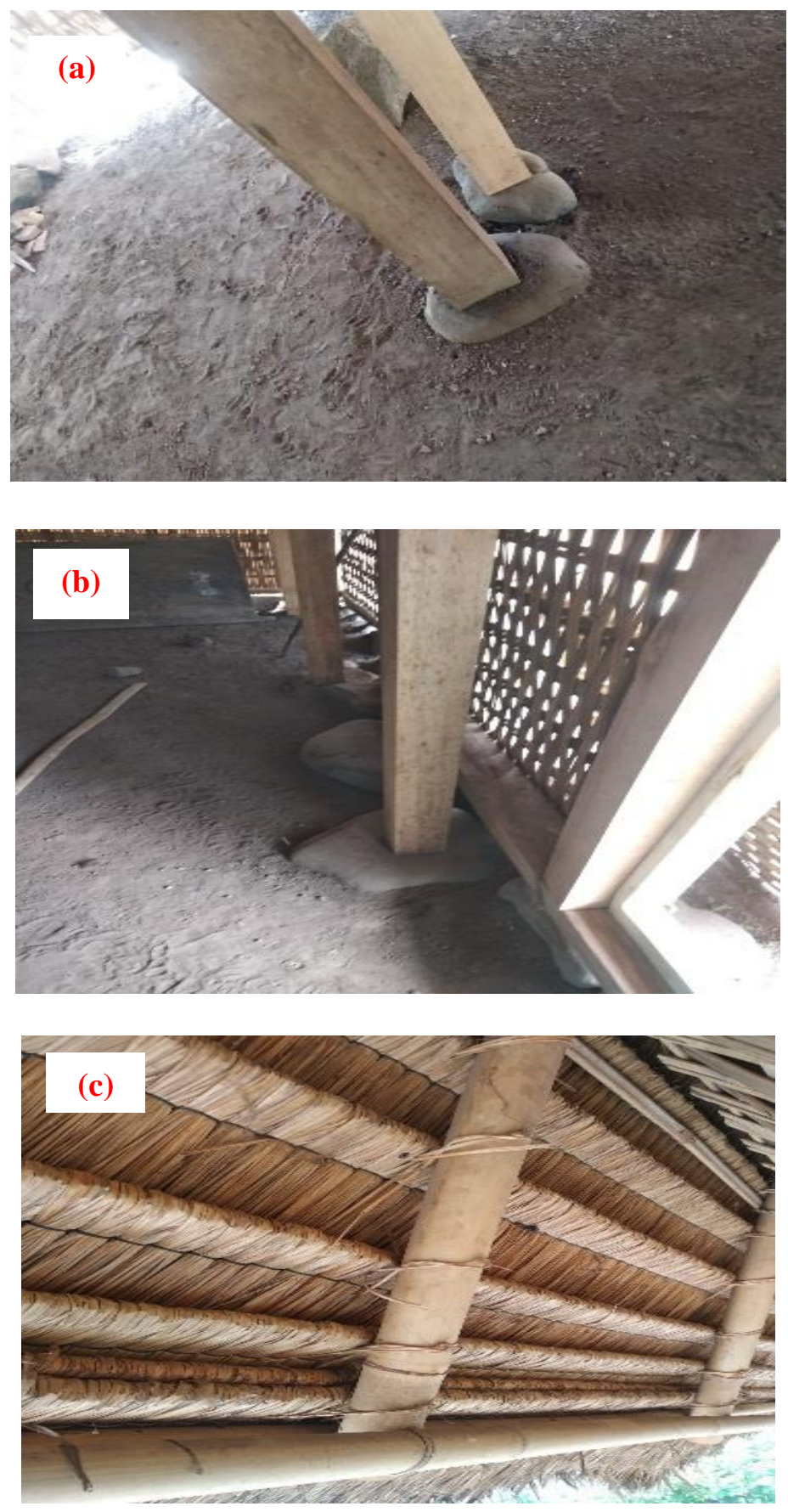

Figure 3. a) Floor, b) Pole, c) Roof Source: researcher documentation December 2020 
Aside from using particular materials for building their houses, the people of Dasan Beleq Hamlet also preserved local wisdom reflected by applying customary values in certain rules and rituals, carried out in the process of building the house. For society, local wisdom was a legacy from generation to generation that should be preserved. They believed that customary, religious, and cultural values were systems that go hand in hand (Wahyudin, 2018). The awareness for maintaining the local wisdom grew without any coercion as the people's appreciation for the environment where they lived. The society's compliance to the customary law and local wisdom was considered a significant cause for the perseverance of the Dasan Beleq traditional house for disaster mitigation efforts (Sabrina \& Prayitno, 2010). Some types of local wisdom represented in the Dasan Beleq traditional house construction system could be seen in the table 2 below:

Table 2. Local Wisdom on the Construction of Traditional Houses in Dasan Beleq Hamlet

\begin{tabular}{ll}
\hline \multicolumn{1}{c}{ Local wisdom } & \multicolumn{1}{c}{$\begin{array}{c}\text { Implementation in the traditional community of } \\
\text { Dusun Beleq }\end{array}$} \\
\hline $\begin{array}{l}\text { Types of traditional house } \\
\text { buildings }\end{array}$ & $\begin{array}{l}\text { There are five types of traditional houses (Bale) which are } \\
\text { differentiated according to their function }\end{array}$ \\
\hline $\begin{array}{l}\text { Rituals before house } \\
\text { construction }\end{array}$ & $\begin{array}{l}\text { Implementation of Diwasa, namely the ritual of looking } \\
\text { for a good day to start the process of building a traditional } \\
\text { house in Dasan Baleq Hamlet }\end{array}$ \\
\hline $\begin{array}{l}\text { The ritual of selecting } \\
\text { traditional house materials }\end{array}$ & $\begin{array}{l}\text { Purify traditional house building materials that come from } \\
\text { nature. Purification is carried out by praying together, } \\
\text { reading yasin and tahlil, and other traditional religious } \\
\text { rituals. }\end{array}$ \\
\hline $\begin{array}{l}\text { Selection of the location for } \\
\text { the construction of a } \\
\text { traditional house }\end{array}$ & $\begin{array}{l}\text { The customary elders will lead and determine the best } \\
\text { location to build a traditional house.. The purpose of this } \\
\text { ritual is to place the traditional house in the right place so } \\
\text { that it does not present a danger to its occupants. }\end{array}$ \\
\hline $\begin{array}{l}\text { Prohibition of building } \\
\text { houses back to back }\end{array}$ & $\begin{array}{l}\text { The indigenous people of Dasan Beleq are prohibited from } \\
\text { building houses with their back to back. These rules are } \\
\text { established so that each community respects and } \\
\text { appreciates each other. }\end{array}$ \\
\hline $\begin{array}{l}\text { Prohibition of lighting large } \\
\text { fires during the dry season }\end{array}$ & $\begin{array}{l}\text { People are not allowed to light big fires during the dry } \\
\text { season to avoid fires. This is because the house building } \\
\text { materials made of nature are prone to burning. }\end{array}$ \\
\hline Does not use electricity & $\begin{array}{l}\text { The people of Dasan Beleq Hamlet maintain local wisdom } \\
\text { by not using electricity in their lives. }\end{array}$ \\
\hline
\end{tabular}


Based on table 2, it can be seen that in building their houses, the people of Dasan Beleq Hamlet always paid attention to the determined customary rules and values. Based on its function, the house had five different types, namely Sambi, Berugak, Traditional Kitchen, Bale Sembeq, and Penggalan. Sambi functioned as a storage area for food (rice). Berugak served as a place for a casual gathering with fellow citizens. Additionally, the traditional kitchen was used specifically for cooking during traditional events. In traditional kitchens, to maintain the sanctity of the food, women allowed to cook were those who had not yet gotten menstruation and had been menopause. Moreover, Bale Sembeq worked as a place to perform sembeq. Sembeq was part of traditional activities for giving signs/symbols using betel nuts on someone's forehead. In addition, Penggalan was used to carry out some customary activities. This building had a lower size than others.

The use of natural building materials required the society to uphold customary values in the process of taking the resources. For the indigenous Sasak tribe people, the process of building a residence should always consider the natural, cultural and religious elements (Sukawi \& Zulfikri, 2010). Before the house building process began, the community always performed several significant rituals with the aim that the house provided safety and comfort for its residents. The customary ritual started with selecting the house location by the customary leader, choosing the best time or day to build the house, and washing the natural building materials. The form of the Dasan Beleq traditional house can be seen in Figure 4a. 

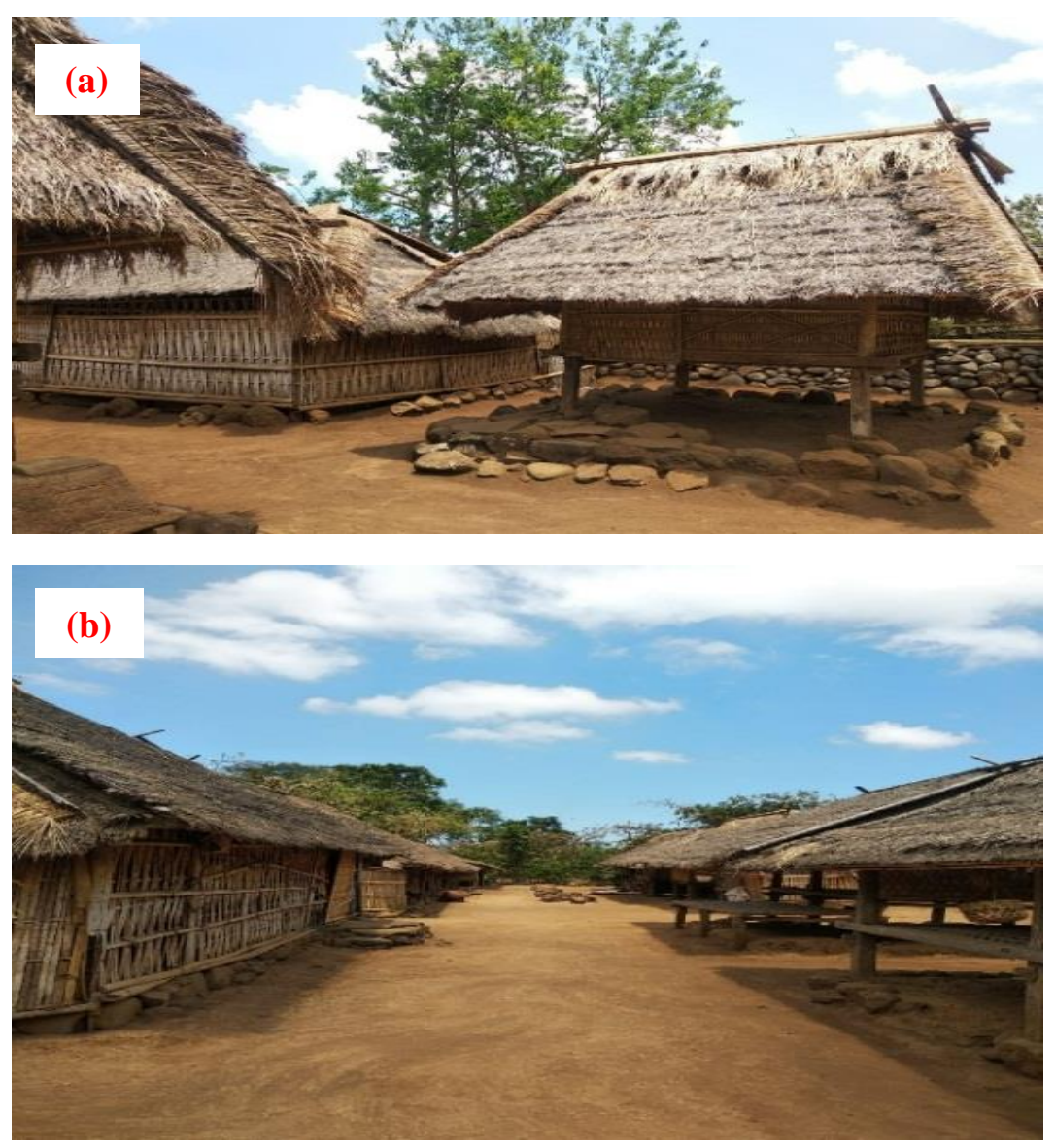

Figure 4. a. the form of the Dasan Beleq traditional house b. the position of the Dasan Beleq traditional house Source: researcher documentation December 2020

Besides carrying out some traditional rituals before building a house, the people of Dasan Beleq Hamlet also adhered to a belief not to build houses with back-to-back positions. The position of the Dasan Beleq traditional house can be seen in the Figure $4 \mathrm{~b}$. This certainty was aimed for mutual respect between the fellow communities. In the dry season, people were prohibited from making a too big fire since it was a source of disaster and calamities, regarding all materials for building the house were flammable. The community's commitment to preserving local wisdom was also realized in the absence of electricity in their environment. This proved that the people of Dasan Beleq Hamlet considered their local wisdom and customary values should be commonly applied as hereditary. The use of natural materials and techniques by considering the local wisdom was evidenced as a good earthquake mitigation effort. 


\section{CONCLUSIONS}

The form of earthquake mitigation based on local wisdom in the Dasan Beleq traditional house was represented by the materials and construction techniques used. Each part of the house had a central role in resisting earthquake shocks. Connection techniques for ropes and pegs between posts, roof, poles, and floors were made using natural materials and arranged according to the believed rules for building earthquake-resistant houses.

Besides the construction techniques and materials used, the people always maintained the local wisdom and customary values reflected by implementing some rituals and beliefs including building particular types of traditional houses, applying rituals for choosing a good day (diwasa), selecting and purifying materials, selecting construction sites, prohibiting the buildings with back to back position, prohibiting for making large fires in the dry season, as well having a prohibition on the use of electricity. Local wisdom that reflected through the rituals and beliefs of the community has a unique value and strength of the earthquake disaster mitigation. This is distinguishes the role of Dasan Beleq traditional house as an earthquake mitigation from several previous studies that only focus on materials and techniques for building earthquake-resistant houses.

Local wisdom which is reflected through the rituals and beliefs of the community has a unique value and strength in earthquake disaster mitigation efforts. This is what distinguishes the role of the Dasan Beleq traditional house as an earthquake mitigation effort from several previous studies that only focus on materials and techniques for building earthquake-resistant houses.

\section{E. ACKNOWLEDGMENTS}

Thanks to LPDP (Institute for Educational Fund Management) Republic of Indonesia for funding the sustainability of this research.

\section{F. REFERENCES}

Alam, A., Mcgregor, A., \& Houston, D. (2018). Neither sensibly homed nor homeless: re-imagining migrant homes through more-than-human relations. Social \& Cultural Geography, 00(00), 1-24. https://doi.org/10.1080/14649365.2 018.1541245

Arief, A. Z., \& Subadyo, A. T. (2017). Sustainability in Architecture of traditional Sasak settlements in Lombok. International Conference "Sustainable Development Goals 2030 Challenges and Its Solutions", 337-351.

Baghel, A., \& Thakkar, A. (2017). Bamboo: A Resilient Material for 
Mass Housing in Earthquake Prone Zones of Gujarat. Sustainable Build Environment International Conference, 1-19.

Bermudez, J., Crane, T., Sullivan, P., Barnes, J., Dretske, F., Kamm, F., Leiter, B., Price, H., Shoemaker, S., Mellor, D. H., Lucas, J. R., \& Husserl, E. (n.d.). International Library of Philosophy Recent titles in the ILP: The Facts of Causation The Conceptual Roots of Mathematics.

Dahliani, Soemarno, I., \& Setijanti, P. (2015). LOCAL WISDOM IN BUILT ENVIRONMENT IN GLOBALIZATION ERA. International Journal of Education and Research, 3(6), 157-166.

Hairumini, Setyowati, D. L., \& Sanjoto, T. B. (2017). Kearifan Lokal Rumah Tradisional Aceh sebagai Warisan Budaya untuk Mitigasi Bencana Gempa dan Tsunami. Journal of Educational Social Studies, 6(1), 37-44.

Husein, S. (2015). Bencana Gempabumi. Proceeding of DRR Action Plan Workshop: Strengthened Indonesian Resilience: Reducing Risk from Disasters.

Ibrahim, W. (2011). Arsitektur Tradisional Kenali Salah Satu Kearifan Lokal Daerah Lampung. Jurnal Rekayasa, 15(1), 69-76.

Karima, T., Wijaya, S. K., Rosid, M. S., Rohadi, S., \& Perdana, Y. H. (2020). Characterization of Lombok Earthquakes on JulyAugust 2018 using Focal Mechanism Analysis. IOP Conference Series: Materials Science and Engineering, 854(1). https://doi.org/10.1088/1757899X/854/1/012042

Komalasari, F. D., Hamdani, Umar, H., Suryani, I., Juliana, Juliani,
Nursaptini, \& Tahir, M. (2020). Nilai Kearifan Lokal Dalam Rumah Adat Limbungan Suku Sasak. Jurnal Dinamika Sosial Budaya, 22(2), 158-164.

Mac, J., \& Robinson, E. (2001). BEING AND TIME.

Maknun, J., Busono, T., \& Nuryanto. (2016). Disaster-friendly sundanese traditional building construction. IOP Conference Series: Materials Science and Engineering, 128(1). https://doi.org/10.1088/1757899X/128/1/012017

Marlina, Sumarmi, \& Astina, I. K. (2020). Sustainable marine ecotourism management: A case of marine resource conservation based on local wisdom of bajo mola community in wakatobi national park. Geojournal of Tourism and Geosites, 32(4), 1317-1323. https://doi.org/10.30892/GTG.3241 9-575

Nugroho, S. P. (2018). 32.129 Unit Rumah Rusak Akibat Gempa Lombok Telah Diverifikasi, Upaya Perbaikan Rumah Terus Dilakukan. BNPB.

Nur, A. M. (2010). Gempa Bumi, Tsunami Dan Mitigasinya. Jurnal Geografi, $7(1)$. https://doi.org/10.15294/jg.v7i1.92

Pradono, M. H. (2018). Kajian Kerentanan Bangunan Pasca Gempa Lombok 5 Agustus 2018. Jurnal Alami: Jurnal Teknologi Reduksi Risiko Bencana, 2(2), 82. https://doi.org/10.29122/alami.v2i2 .3109

Rapoport, A. (1969). House Form and Culture - Foundation of Cultural Geography Series. Prentice-Hall, Inc.

Sabrina, R., \& Prayitno, G. (2010). PELESTARIAN POLA 
PERMUKIMAN TRADISIONAL SUKU SASAK DUSUN LIMBUNGAN KABUPATEN LOMBOK TIMUR. Jurnal Tata Kota Dan Daerah, 1(2), 87-108.

Sugiyono. (2016). Metode Penelitian Kuantitatif, Kualitatif dan $R \& D$. PT. Alfabet.

Sukawi, \& Zulfikri. (2010). Adaptasi Arsitektur Sasak Terhadap Kondisi Iklim Lingkungan Tropis Studi Kasus Desa Adat Sade Lombok. Jurnal Berkala Teknik, 1(6), 339346.

Suparmini, Setyawati, S., \& Sumunar, D. R. S. (2014). MITIGASI BENCANA BERBASIS KEARIFAN LOKAL MASYARAKAT BADUY. Jurnal Penelitian Humaniora, 19(1), 4764.

Syamsuri, F. A., \& Sufianto, H. (2020). Earthquake-Resistant Design Principles of the Traditional House in Lombok Island. 195(Hunian 2019), 35-39.

Triyadi, S., Sudradjat, I., \& Harapan, A. (2010). Kearifan Lokal pada Bangunan Rumah Vernakular di Bengkulu dalam Merespon Gempa, Studi Kasus: Rumah Vernakular di Desa Duku Ulu. Local Wisdom, 2(1), 1-7.

Tuffour, I. (2017). A Critical Overview of
Interpretative Phenomenological Analysis: A Contemporary Qualitative Research Approach. Journal of Healthcare Communications, 02(04), 1-5. https://doi.org/10.4172/24721654.100093

Wahyudin, D. (2018). Identitas Orang Sasak: Studi Epistemologis terhadap Mekanisme Produksi Pengetahuan Masyarakat Suku Sasak. Jurnal Penelitian Keislaman, 14(1), 52-63. https://doi.org/10.20414/jpk.v14i1. 493

Widisono, A. (2019). The Local Wisdom on Sasak Tribe Sade Hamlet Central Lombok Regency. Local Wisdom: Jurnal Ilmiah Kajian Kearifan Lokal, 11(1). https://doi.org/10.26905/lw.v11i1.2 711

Wismabrata, M. H. (2018). 5 Fakta Terbaru Gempa Lombok, Kerugian Rp 8,8 Triliun hingga Kekurangan Air Bersih. Kompas. Com.

Zulfadrim, Z., Toyoda, Y., \& Kanegae, H. (2018). The implementation of local wisdom in reducing natural disaster risk: A case study from West Sumatera. IOP Conference Series: Earth and Environmental Science, 106(1), 0-6. https://doi.org/10.1088/17551315/106/1/012008 